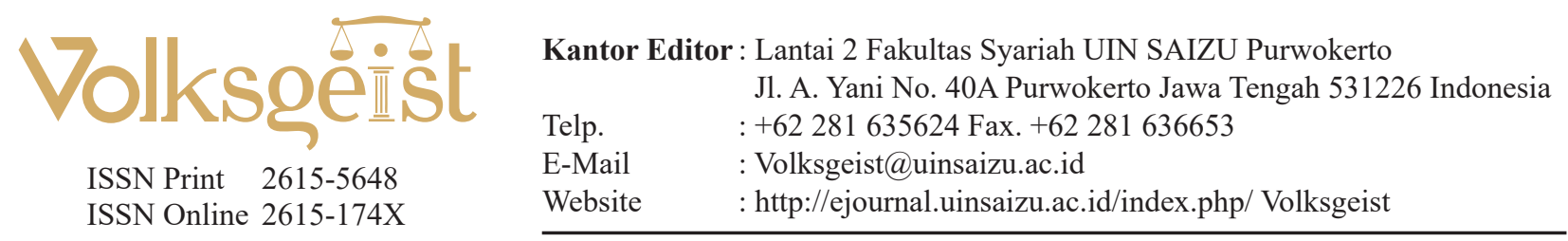

\title{
Perlindungan Hukum Bagi Kurir dalam Sistem Cash on Delivery Belanja Online
}

\author{
Riska Natagina Putri, ${ }^{1}$ Siti Nurul Intan Sari Dalimunthe, ${ }^{2}$ \\ 1,2Universitas Pembangunan Nasional "Veteran" Jakarta \\ ${ }^{1}$ Email: riskanataginap@upnvj.ac.id
}

\begin{abstract}
Abstrak
Penelitian ini bertujuan untuk mengetahui kedudukan hukum kurir dalam kegiatan jual beli secara online, terutama dalam sistem pembayaran $\mathrm{COD}$, dan untuk mengetahui perlindungan hukum yang dapat diberikan kepada kurir dalam sistem pembayaran COD, terlebih perlindungan hukum bagi kurir terhadap pembeli yang wanprestasi dan menolak barang yang dipesannya. Metode yang digunakan dalam penelitian ini adalah metode yuridis normatif dengan cara meneliti bahanbahan pustaka atau sumber data sekunder, yaitu peraturan perundang-undangan, buku-buku, dan penelitian-penelitian hukum. Berdasarkan metode tersebut, maka penelitian dilakukan dengan pendekatan perundang-undangan (statute approach) dan pendekatan kasus (case approach). Hasil penelitian menunjukkan bahwa kedudukan hukum kurir dalam sistem COD belanja online adalah sebagai penerima titipan, sebagai orang yang menggantikan perusahaan jasa pengiriman barang dalam menjalankan kuasa dari penjual, dan sebagai penerima pembayaran dari pembeli. Perlindungan hukum yang dapat diberikan kepada kurir dalam sistem COD belanja online adalah dengan menjamin bahwa kurir tidak bertanggung jawab atas ketidaksesuaian atau kerusakan barang yang bukan disebabkan oleh kesalahan atau kelalaiannya.
\end{abstract}

Kata Kunci: Perlindungan hukum; kurir; cash on delivery; belanja online.

\section{Abstract}

This study aims to find out the legal position of the couriers in online shopping activities, especially in the payment method of COD (Cash on Delivery); the legal protection that can be given to the COD couriers; and the legal protection for the couriers who encounter buyers who default and refuse the goods they ordered. The method used in this research is the normative juridical method by examining library materials or secondary data sources, namely laws and regulations, books, and legal studies. Based on this method, the research was conducted using a statutory approach and a case approach. The results show that the legal position of the couriers in the online shopping with COD method of payment is as a recipient of a deposit, as a person who represents a freight forwarder in carrying out the power of attorney from the seller, and as a recipient of payment from the buyer. The legal protection that can be given to the couriers is ensuring that the couriers are not responsible for any discrepancy or damage to goods that are not caused by his mistake or negligence.

Keywords: Legal protection; couriers; cash on delivery; online shopping. 


\section{Sejarah Artikel}

Dikirim: 06 Oktober 2021

Direview: 16 November 2021

Diterima: 23 November 2021

Diterbitkan: 30 November 2021

\section{PENDAHULUAN}

Tidak dapat dipungkiri bahwa internet merupakan media penting dalam menyediakan informasi bagi dan/atau kepada masyarakat sekarang ini. Bahkan majunya perkembangan zaman. Internet merupakan lompatan teknologi, yang telah merubah cara pandang batas terhadap bisnis lokal maupun global, dimana model bisnis era global saat ini menggunakan sistem dengan cara yang tidak perlu untuk bertatap muka secara langsung, cukup hanya dengan melakukan transfer data via internet saja. ${ }^{1}$ Selain itu, internet juga dirasa memberikan manfaat baik dalam bidang perdagangan, dimana para pelaku usaha dapat memasarkan produk yang dijualnya secara lebih mudah, cepat, dan praktis dan para konsumen bisa mendapatkan produk diinginkannya dengan mudah dan dengan harga yang cenderung lebih terjangkau melalui kegiatan jual beli atau belanja secara online. Belanja online merupakan kegiatan jual beli dengan ciri khas prosesnya yang mudah, dimana tidak bertemunya penjual dan pembeli secara langsung serta dapat dilakukan kapan pun dan dimana pun. ${ }^{2}$

Kemudahan yang didapatkan dari belanja online membuat kegiatan tersebut semakin digemari oleh konsumen Indonesia. Tercatat

1 Mabarroh Azizah, "PENERAPAN ETIKA BISNIS ISLAM DALAM TRANSAKSI JUAL BELI DARING DI TOKO ONLINE SHOPEE," Humani (Hukum Dan Masyarakat Madani) 10, no. 1 (May 22, 2020): 83-96, https://doi.org/10.26623/HUMANI. V10I1.1848.

2 Ainul Yaqin, "Akibat Hukum Wanprestasi dalam Jual Beli Online menurut Undang-Undang Informasi dan Transaksi Elektronik," Jurnal Dinamika 25, no. 6 (2019): 10. dalam hasil survei oleh We Are Social pada April 2021, sebanyak 88,1\% (delapan puluh delapan koma satu persen) pengguna internet di Indonesia lebih suka untuk membeli produk yang diinginkan secara online. ${ }^{3}$ Terlebih lagi, sejak mewabahnya virus COVID-19 dan pemberlakuan kebijakan-kebijakan pemerintah dalam menangani virus tersebut membuat sebagian besar masyarakat Indonesia berada di rumah, terjadi peningkatan terhadap kegiatan belanja online sebanyak $25 \%$ (dua puluh lima persen) hingga $30 \%$ (tiga puluh persen) di Indonesia. $^{4}$

Selain proses jual beli yang mudah, sistem pembayaran yang digunakan dalam belanja online juga praktis. Pembeli umumnya melakukan transfer sejumlah uang seharga produk yang dibelinya kepada penjual melalui rekening bank. Namun, pembayaran dengan sistem tersebut ternyata memiliki risiko yang cukup besar dikarenakan kemungkinan adanya penipuan atau kecurangan oleh penjual. Berdasarkan hal tersebut muncul sistem pembayaran lain yang dinilai lebih aman dengan tingkat risiko yang lebih kecil, yaitu cash on delivery (selanjutnya disebut sebagai COD). COD merupakan sistem pembayaran dalam belanja online dimana pembeli dapat membayar barang yang dipesannya secara tunai ketika barang tersebut tiba di tujuan. Metode pembayaran ini merupakan metode pembayaran yang paling digemari oleh konsumen di Indonesia. Hal tersebut dibuktikan dengan data Statistik E-Commerce 2020 yang dirilis oleh Badan Pusat Statistik (BPS) yang menunjukkan bahwa dari sekitar 17 (tujuh belas) ribu usaha

3 Andrea Lidwina, "Penggunaan E-Commerce Indonesia Tertinggi di Dunia," Databoks, 21 April 2021, https:/databoks.katadata.co.id/datapublish/2021/06/04/ penggunaan-e-commerce-indonesia-tertinggi-di-dunia.

4 Bidara Pink, "YLKI Catat Selama Pandemi Aktivitas Belanja Online Meningkat Hingga 30\%," Kontan.co.id, 14 Januari 2021, https://nasional.kontan. co.id/news/ylki-catat-selama-pandemi-aktivitas-belanjaonline-meningkat-hingga-30. 
online yang ada di Indonesia, 73\% (tujuh puluh tiga persen) di antaranya menggunakan metode pembayaran COD. ${ }^{5}$

Sistem pembayaran COD cukup memberikan keuntungan bagi pembeli, dimana pembeli dapat mengecek kembali barang yang dipesannya ketika telah tiba. Selanjutnya, jika terjadi ketidaksesuaian terhadap barang yang dipesannya, pembeli dapat mengajukan pengembalian kepada penjual. Namun, seperti metode pembayaran lainnya, COD juga dapat menimbulkan masalah. Tidak sedikit pembeli yang merasa barang pesanannya tidak sesuai yangkemudianmenolakuntukmembayarbarang pesanannya, bahkan meminta pengembalian dana langsung kepada kurir. Padahal, dalam hal ini kurir hanya berperan sebagai perantara antara penjual dan pembeli dalam pengantaran barang dan penerimaan pembayaran, serta tidak bertanggungjawab atas ketidaksesuaian barang yang diterima. Hal tersebut tentu menyimpang terhadap ketentuan dalam Pasal 1313 Kitab Undang-Undang Hukum Perdata (selanjutnya disebut sebagai KUH Perdata), dimana pembeli dan penjual telah mengikatkan dirinya dalam suatu perjanjian jual beli. Atas hal tersebut maka keduanya harus memenuhi prestasi yang telah diperjanjikan, dimana dalam hal sistem pembayaran COD, pembeli wajib membayarkan barang yang dipesannya ketika barang tersebut telah diterimanya. Dalam hal terjadinya ketidaksesuaian, maka hal tersebut bukan merupakan tanggung jawab kurir.

Tindakan wanprestasi dalam kegiatan belanja online sekarang ini bukanlah hal yang baru terjadi. Berbagai penelitian telah banyak dilakukan selama beberapa tahun terakhir untuk menelaah tindakan wanprestasi tersebut. Namun, setelah menelaah beberapa penelitian, ditemukan bahwa penelitian-penelitian

5 Anindhita Maharrani, "Orang Indonesia Pilih CoD saat Belanja Online,” Lokadata, 19 Januari 2021, https://lokadata.id/artikel/orang-indonesia-pilih-codsaat-belanja-online. sebelumnya dominan hanya berfokus kepada urgensi perlindungan hukum bagi pihak pelaku usaha ${ }^{6}$, perlindungan hukum bagi konsumen ${ }^{7}$ dalam kegiatan jual beli online, dan perlindungan hukum bagi semua pihak yang terlibat dalam sistem COD pada marketplace ${ }^{8}$. Penulis masih belum menemukan adanya penelitian yang secara eksplisit berfokus kepada pembahasan mengenai kedudukan kurir dan pertanggungjawaban terhadap kurir pengantar barang yang dirugikan dan peran negara dalam menjamin perlindungan hukum bari kurir, terutama dalam sistem COD. Di samping itu, beberapa penelitian yang membahas mengenai sistem pembayaran elektronik melalui aplikasi, ${ }^{9}$ melalui transfer rekening antar bank, ${ }^{10}$ ataupun menggunakan kartu kredit bank $^{11}$ masih mendominasi penelitian mengenai sistem pembayaran yang digunakan dalam jual beli online di Indonesia sejauh ini. Padahal, seiring berjalannya waktu dan semakin maraknya penggunaan sistem pembayaran COD, sistem

6 Chory Ayu Sugesti, Si Ngurah Ardhya, dan Muhamad Jodi Setianto, "Perlindungan Hukum terhadap Pelaku Usaha Online Shop yang Mengalami Kerugian yang Disebabkan oleh Konsumen di Kota Singaraja," Jurnal Komunitas Yustisia Universitas Pendidikan Ganesha 3, no. 3 (2020): 166-75.

7 Heldya Natalia Simanullang, "Perlindungan Hukum terhadap Konsumen dalam Transaksi E-Commerce," Melayunesia Law 1, no. 1 (2017): 11126.

8 Grace Evelyn Pardede and Ferdinand Sujanto, "URGENSI PENYERAGAMAN KEBIJAKAN COD PADA MARKETPLACE INDONESIA DEMI MEWUJUDKAN PERLINDUNGAN HUKUM" 1 , no. 2 (2021): 12-28.

9 Erwin Asmadi, “Aspek Perlindungan Hukum bagi Konsumen dalam Penggunaan Aplikasi Pembayaran Elektronik (Electronic Payment)," Doktrina : Journal of Law 1, no. 2 (2018): 90-103.

${ }^{10}$ Teguh Tresna Puja Asmara dan Tri Handayani, "Ketidakpastian Hukum Penggunaan Kode Unik dalam Sistem Pembayaran E-Commerce," Jurnal Penelitian Hukum De Jure 19, no. 4 (2019): 503-16.

${ }^{11}$ Sri Wahyuni, "Perlindungan Hukum Terhadap Konsumen Pemilik Kartu Kredit dalam Transaksi E-Commerce (Studi Pada Bank X Medan)" (Universitas Sumatera Utara, 2019). 
pembayaran tersebut juga perlu ditelaah dan diteliti mengenai permasalahan-permasalahan atau ketidakpastian hukum yang mungkin terjadi dalam penggunaannya.

Berdasarkan uraian di atas, maka tujuan dari penulisan ini adalah untuk membahas mengenai kedudukan kurir sebagai perantara antara penjual dan pembeli dalam jual beli online, terutama dalam sistem pembayaran COD, juga untuk mengetahui perlindungan hukum yang dapat diberikan kepada kurir sebagai pihak yang berhubungan langsung dengan pembeli dalam sistem pembayaran COD.

Penelitian ini dilakukan menggunakan jenis penelitian yuridis normatif, yang mana penelitian ini akan mengacu kepada bahanbahan hukum yang ada, seperti kaidahkaidah hukum, asas-asas hukum, peraturan perundang-undangan, dokrin dan ajaran-ajaran hukum, literatur-literatur hukum, dan teoriteori hukum. ${ }^{12}$ Adapun pendekatan masalah yang digunakan dalam penelitian ini adalah dengan menggunakan pendekatan perundangundangan (statue approach) dan pendekatan kasus (case approach).

\section{PEMBAHASAN}

\section{Kedudukan Hukum Kurir dalam Sistem Cash on Delivery Belanja Online}

Pada dasarnya, kesamaan antara kegiatan jual beli konvensional maupun jual beli online yaitu terdapat setidaknya satu perjanjian yang mengikat pihak-pihak yang terlibat di dalamnya. ${ }^{13}$ Namun, salah satu hal yang membedakan kedua kegiatan jual beli tersebut

\footnotetext{
${ }^{12}$ Nurul Qamar et al., Metode Penelitian Hukum (Legal Research Methods), ed. Abd. Kahar Muzakkir, 1st ed. (Makassar: CV. Social Politic Genius (SIGn), 2017),

13 Hermawan Lumba and Sumiyati, "Pertanggungjawaban Perusahaan Ekspeditur Kepada Konsumen Berdasarkan UU No. 8 Tahun 1999 Tentang Perlindungan Konsumen," Mimbar Keadilan Jurnal Ilmu Hukum, no. 8 (2014): 71-86.
}

adalah pihak-pihak yang terlibat di dalamnya. Jika dalam jual beli konvensional hanya terdapat pihak penjual dan pembeli, lain halnya dengan jual beli online. Dalam jual beli online, terdapat pihak ketiga selaku perantara yang juga ikut terlibat dalam perjanjian jual beli antara penjual dan pembeli. Meskipun tidak terlibat secara langsung, namun pihak perantara tersebut bekerja untuk perusahaan jasa pengiriman barang yang mana telah terikat dalam suatu perjanjian pengiriman barang dengan pengguna jasanya, yaitu penjual. ${ }^{14}$ Subekti berpendapat bahwa perjanjian pengiriman tersebut merupakan perjanjian antara 2 (dua) pihak, yang mana pihak satu menyanggupi untuk membawa barang dari suatu tempat ke tempat lain dengan aman, sedangkan pihak yang lain menyanggupi untung menanggung biaya ongkosnya. ${ }^{15}$ Perjanjian tersebut bersifat berkala sebagaimana dikaitkan dengan Pasal 1601 KUH Perdata, yang mana hubungan perjanjian antara perusahaan jasa pengiriman barang dengan penjual maupun pembeli tidak tetap. ${ }^{16}$

Berdasarkan perjanjian antara penjual dengan perusahaan jasa pengiriman barang tersebut, maka perusahaan jasa pengiriman barang dapat dianggap sebagai pihak yang menerima kuasa dari penjual selaku pemberi kuasa dalam melakukan penyerahan, sebagaimana diatur dalam Pasal 1792 KUH Perdata. Menurut pasal tersebut, perusahaan jasa pengiriman barang bertindak atas nama penjual untuk menyerahkan barang pesanan pembeli. Selanjutnya, agar efektif dan tepat waktunya penyerahan tersebut, perusahaan

${ }^{14}$ Mulyani Zulaeha, "Tanggung Jawab dalam Levering pada Perjanjian Jual Beli secara Online," Lambung Mangkurat Law Journal 4, no. 2 (2019): 179.

15 Nedi Pernando, Busyra Azheri, and Wetria Fauzi, "Perlindungan Hukum Terhadap Konsumen atas Kerusakan Barang Pengguna Jasa Pengiriman Angkutan Online," Journal of Chemical Information and Modeling 4, no. 1 (2021): 136.

16 Lumba dan Sumiyati, 75 
jasa pengiriman barang mempekerjakan kurirkurir yang berperan sebagai perantara untuk mengirimkan barang tersebut langsung ke tangan pembeli. Berkaitan dengan Pasal 1800 KUH Perdata, maka kurir dapat dikatakan sebagai pihak yang menggantikan perusahaan jasa pengiriman barang dalam menjalankan kuasa yang diberikan penjual kepadanya. Dalam hal ini, menurut Pasal 1803 KUH Perdata, maka perusahaan sepenuhnya bertanggung jawab atas kurir yang mewakilkannya dalam menjalankan tugasnya. Perusahaan juga bertanggung jawab, baik atas kesalahan-kesalahan yang dilakukan oleh kurir dengan sengaja, maupun kelalaiankelalaian lain yang terjadi, sebagaimana diatur dalam Pasal 1801 KUH Perdata. Dalam hal pengiriman barang yang dilakukan oleh kurir, maka secara tidak langsung juga dapat dikatakan bahwa kurir merupakan pihak yang dititipkan barang oleh penjual melalui perusahaan jasa pengiriman barang kepada pembeli. Penitipan yang dimaksud merupakan kegiatan yang dilakukan untuk menerima, membawa, dan atau menyampaikan paket dari pengirim kepada penerima dengan memungut biaya. Sesuai dengan ketentuan dalam Pasal 1706 KUH Perdata, kurir selaku penerima titipan wajib menjaga barang yang dipercayakan kepadanya dengan sebaik mungkin seperti ia menjaga barang-barangnya sendiri.

Sama halnya seperti jual beli konvensional, di dalam jual beli secara online pun penyerahan barang yang dibeli sebagai obyek dari jual beli merupakan kewajiban penjual, dan pembeli berkewajiban untuk membayar barang tersebut dengan harga yang telah disepakati, sebagaimana diatur dalam Pasal 1457 KUH Perdata. Kemudian, Pasal 1458 menyatakan bahwa setelah terjadinya kesepakatan mengenai barang dan harga barang tersebut, maka kegiatan jual beli tersebut dianggap telah ada sekalipun barang tersebut belum diserahkan maupun harganya belum dibayarkan. Seperti yang telah diuraikan, penjual dalam melaksanakan kewajibannya untuk menyerahkan barang tersebut kepada pembeli dapat menggunakan bantuan kurir atau perusahaan jasa pengiriman barang sebagaimana disebutkan dalam Pasal 63 ayat (2) PP 80/2019, dengan tetap memastikan ketentuan-ketentuan yang selanjutnya dinyatakan dalam Pasal 64 ayat (1) PP 80/2019, di antaranya: keamanan barang, kelayakan kondisi barang, kerahasiaan barang, kesesuaian barang, dan ketepatan waktu pengiriman barang. Dalam hal biaya ongkos yang dikenakan untuk pengiriman biasanya ditanggung oleh pembeli digabungkan dengan biaya barang yang dibelinya berdasarkan kesepakatan antara keduanya. Selanjutnya, menurut Pasal 64 ayat (2) PP 80/2019, penjual tidak dapat membebankan biaya pengiriman kepada pembeli, kecuali berdasarkan kesepakatan antara keduanya.

Sedikit berbeda halnya ketika penyerahan barang tersebut dilakukan menggunakan sistem pembayaran COD. Dalam sistem pembayaran COD, kurir tetap berperan sebagai seseorang yang ditunjuk untuk menggantikan kuasa perusahaan jasa pengiriman barang. Namun, selain itu, kurir juga berperan sebagai seseorang yang dikuasakan untuk menerima pembayaran dari pembeli. Dikarenakan dalam jual beli online pihak penjual dan pembeli tidak bertemu langsung, maka pembayaran secara tunai pun tidak dapat dilaksanakan dengan bertatap muka. Hal tersebut sesuai dengan ketentuan dalam Pasal 1385 KUH Perdata, yang menyatakan bahwa pembayaran harus dilakukan kepada si berpiutang (penjual) atau kepada seseorang yang dikuasakan olehnya (kurir). Berdasarkan ketentuan pasal tersebut, maka pembeli dalam sistem COD berkewajiban membayarkan uang seharga barang kepada kurir. Selanjutnya, menurut Pasal 1478 KUH Perdata, penjual tidak wajib menyerahkan barang yang disepakati apabila pembeli belum melakukan pembayaran. Berlawanan dengan pasal tersebut, dalam sistem pembayaran COD, 
setelah terjadinya kesepakatan harga atas suatu barang, maka penjual wajib menyerahkan barang tersebut melalui kurir dan pembeli wajib membayar dengan harga yang telah disepakati kepada kurir pada saat barang tersebut tiba di alamat tujuan.

Selanjutnya, berpedoman pada Pasal 1802 KUH Perdata, jika biaya pembayaran dalam sistem COD telah diterima oleh kurir, maka kurir wajib memberikan biaya tersebut kepada perusahaan yang kemudian akan diteruskan kepada marketplace dan penjual. Atas pelaksanaan tugasnya tersebut pun kurir memiliki hak untuk mendapatkan upah sesuai dengan perjanjian pekerjaan dengan perusahaan jasa pengiriman barang, sebagaimana merujuk pada Pasal 1808 KUH Perdata. Berdasarkan hal tersebut juga, dapat dikatakan bahwa kuasa yang diberikan kepada kurir untuk menyerahkan barang dalam sistem pembayaran COD berakhir, sebagaimana diatur dalam Pasal 1813 KUH Perdata. Selanjutnya, merujuk pada Pasal 1601 huruf a KUH Perdata, dalam hal kurir telah menyelesaikan pekerjaannya dalam waktu tertentu, maka kurir berhak menerima upah dari perusahaan jasa pengiriman barang.

\section{Perlindungan hukum bagi Kurir dalam Sistem Cash on Delivery Belanja Online}

Pembayaran dengan sistem COD merupakan salah satu langkah dalam meningkatkan minat masyarakat dalam berbelanja online, terlebih di masa pandemi COVID-19 ini, dimana hampir semua orang lebih sering berada di rumah. Pembayaran dengan sistem COD juga memudahkan masyarakat yang tidak memiliki rekening bank atau $e$-wallet untuk tetap bisa belanja online. Namun, di balik banyaknya kelebihan dan keuntungan yang didapatkan dari sistem COD tersebut, tidak sedikit juga permasalahan hukum yang timbul. Akhir-akhir ini banyak terjadi beberapa kasus yang disebabkan oleh pembeli yang menolak untuk membayar barang yang dipesannya dalam sistem $\mathrm{COD}^{17}$, sehingga menyulitkan kurir sebagai pihak perantara dalam menjalankan pekerjaannya dan menerima pembayaran. Sistem pembayaran COD sekarang ini justru menjadi sarana bagi pembeli untuk melampiaskan protesnya atas barang yang tidak sesuai kepada kurir.

Dalam sistem pembayaran COD, apabila barang yang dipesan oleh pembeli tidak sesuai dengan apa yang disepakati sebelumnya dengan penjual, maka kurir tidak wajib bertanggung jawab terhadap hal tersebut dikarenakan hal tersebut bukan merupakan kewajiban kurir, artinya kurir hanya menjalankan kewajibannya berdasarkan apa yang telah dikuasakan kepadanya. Hal tersebut juga sesuai dengan Pasal 1797 KUH Perdata yang menyebutkan bahwa orang yang menjalankan kuasa tidak boleh melakukan apa pun yang melampaui batas kuasanya, dalam hal ini hal yang melampaui tersebut adalah bertanggung jawab atas ketidaksesuaianatau kerusakan barang yang bukan merupakan kesalahan kurir. Kurir pun bahkan tidak mengetahui mengenai detil transaksi antara penjual dengan pembeli. Walaupun kurir merupakan pihak yang berhubungan langsung dengan pembeli, namun tidak terdapat hubungan hukum di antara keduanya. ${ }^{18}$ Seperti yang telah dijelaskan, kurir hanya berperan sebagai perantara antara penjual dan pembeli dalam hal penyerahan barang. Kedudukan kurir dalam sistem COD belanja online adalah sebagai pihak yang menggantikan kuasa perusahaan pengiriman barang dalam hal pengantaran barang. Ketidaksesuaian atau

17 Conney Stephanie, "Rentetan Kasus COD, Mengancam Kurir Hingga Paket Tak Bertuan," Kompas.com, 07 Juni 2021, https://tekno.kompas. com/read/2021/06/07/09550027/rentetan-kasus-codmengancam-kurir-hingga-paket-tak-bertuan?page=all.

18 Suriyadi, "Tanggung Gugat Penjual Dan Jasa Pengantaran Dalam Transaksi Jual Beli Online Dengan Metode Cash on Delivery," El-Iqtishady Jurnal Hukum Ekonomi Syari'ah 3, no. 1 (2021): 35. 
kerusakan barang pun tidak dapat dijadikan alasan pembenar bagi pembeli untuk menolak melakukan pembayaran, apalagi memaki atau melakukan hal yang di luar batas terhadap kurir. Terlebh jika ketidaksesuaian atau kerusakan barang tersebut bukan dikarenakan kesalahan atau kelalaian dari kurir.

Terhadap penolakan pembayaran yang dilakukan oleh pembeli dalam sistem COD, maka pembeli tersebut telah sangat merugikan kurir. Pertama, dari segi tenaga, kurir harus mengeluarkan tenaga yang ekstra ketika pembeli menolak membayar terlebih jika pembeli tidak mengerti bahwa ketidaksesuaian atau kerusakan bukan merupakan tanggung jawab kurir, karena kurir harus memberikan penjelasan kepada pembeli yang tidak mengerti atas hal tersebut dan itu sangat membuang tenaga. Kedua, pengantaran barang ke alamat-alamat lainnya menjadi terhambat dan lebih lama dikarenakan kurir harus menghabiskan waktu dalam memberi penjelasan kepada pembeli yang tidak mengerti mengenai mekanisme pembayaran COD. Ketiga, jika pembeli menolak membayar dan kemudian kurir kembali ke gudang dengan keadaan paket telah dibuka bungkusnya, maka terdapat kemungkinan kurir akan terkena teguran atau bahkan sanksi oleh atasan atas hal tersebut. Sebab, kebijakan di beberapa perusahaan pengiriman barang mengharuskan kurir untuk membayar barang COD yang tidak dibayar oleh pembeli. ${ }^{19}$ Padahal, pada dasarnya, barang-barang yang dipesan dan dibayar dengan sistem COD, tidak boleh dibuka bungkusnya sebelum dilakukannya pembayaran. Atas dasar hal tersebut, maka kurir dalam sistem pembayaran COD belanja online dirasa sangat perlu untuk mendapatkan perlindungan hukum, mengingat dalam sistem COD kurir memegang

\footnotetext{
${ }^{19}$ Ramdan Febrian, "Sialnya Jadi Kurir Pengiriman Paket: Tanggung Jawab Besar Tapi Perlindungan Hukum Minim," VOI, 17 Mei 2021, https://voi.id/bernas/52100/ sialnya-jadi-kurir-pengiriman-paket-tanggung-jawabbesar-tapi-perlindungan-hukum-minim.
}

peran penting dalam keberhasilan proses jual beli antara penjual dan pembeli. Perlindungan hukum sendiri sangat berkaitan erat dengan hak dan kewajiban dari subyek hukum, yang mana adalah manusia yang memiliki hak dan kewajiban secara hukum. ${ }^{20}$

Sebagaimana disebutkan dalam Pasal 17 ayat (2) UU No. 11 Tahun 2008 tentang Informasi dan Transaksi Elektronik, para pihak dalam melakukan transaksi secara elektronik wajib untuk beritikad baik selama transaksi berlangsung. Itikad baik merupakan hal yang sangat penting dalam perjanjian jual beli, baik konvensional maupun online, bahkan dari sebelum adanya kesepakatan. ${ }^{21}$ Itikad baik juga ditegaskan dalam Pasal 1338 ayat (3) KUH Perdata yang mengharuskan adanya itikad baik dalam suatu perjanjian. Dalam jual beli dengan sistem pembayaran COD, itikad baik harus dijalankan dengan benar oleh para pihak yang terlibat, yaitu penjual harus menyerahkan barang sesuai dengan yang disepakati dan pembeli harus membayar barang tersebut ketika barang tersebut telah sampai. ${ }^{22}$ Apabila itikad baik tersebut dilaksanakan dengan benar dengan tidak mengurangi atau mengabaikan hak-hak para pihak, maka permasalahan-permasalahan yang mungkin terjadi dapat dihindari. Dalam sistem pembayaran COD, transaksi dianggap belum berakhir ketika pembeli belum membayarkan barang pesanannya kepada kurir. Maka, pembeli harus tetap beritikad baik dan membayar barang pesanannya tersebut kepada kurir sebelum dibuka. Jika paket dibuka dan

20 Arikha Saputra, Muzayanah, dan Fitika Andraini, "Penerapan Perjanjian dalam Hubungan Kerja dan Perlindungan Hukum bagi Driver Online," Jurnal Komunikasi Hukum (JKH) 6, no. 1 (2020): 266,

${ }^{21}$ Rafni Suryaningsih Harun, Weny A. Dungga, dan Abdul Hamid Tome, "Implementasi Asas Itikad Baik dalam Perjanjian Transaksi Jual Beli Online," Jurnal Legalitas 12, no. 2 (2018): 94.

22 Setiawati Gulo, "Transaksi E-Commerce Dengan Sistem Cash on Delivery Dalam Perspektif Peraturan Perundang-Undangan Di Indonesia" (Universitas Jambi, 2021), 
ingin dikembalikan karena tidak sesuai, maka pembeli tetap wajib membayarkan pesanan tersebut kepada kurir. Selanjutnya, keluhan dan pengembalian dapat diajukan kepada penjual melalui fitur yang terdapat dalam marketplace tempatnya membeli barang tadi.

Sama halnya seperti kegiatan jual beli pada umumnya, pembeli dalam jual beli online juga memiliki hak dan kewajiban. Pembeli berhak atas barang yang telah disepakati setelah ia melakukan kewajibannya untuk membayar barang tersebut dengan metode yang telah ditentukan. $^{23}$ Jika pembeli menolak untuk membayar barang pesanannya kepada kurir karena dianggap tidak sesuai dan mengakibatkan kerugian kepada kurir, maka pembeli dalam hal ini harus bertanggung jawab atas kerugian yang dialami kurir tersebut. ${ }^{24}$ Penolakan pembayaran yang dilakukan oleh pembeli tersebut merupakan tindakan wanprestasi dan dapat menghambat kurir dalam melaksanakan, juga menyebabkan kerugian terhadap penjual. Padahal, jika merujuk pada Pasal $1460 \mathrm{KUH}$ Perdata, barang yang dijual tersebut sejak terjadinya kesepakatan atau pembelian telah menjadi tanggungan pembeli, meskipun penyerahannya belum dilakukan, maka penjual berhak menuntut biaya atas barang tersebut. Berdasarkan hal tersebut, maka menurut Pasal 1243 KUH Perdata, pembeli wajib memberikan penggantian biaya kerugian yang dialami karena telah lalai memenuhi perikatannya dengan penjual.

\footnotetext{
${ }^{23}$ Salomo Kevin Davian Simanjuntak, "Tinjauan Yuridis Terhadap Tanggung Jawab Penyelenggara Layanan E-Commerce Terhadap Konsumen Situs Lazada.Co.Id" (Universitas Sumatera Utara, 2019).

24 Alfred Perlin Jaya Lomboe, "Perlindungan Hukum Bagi Driver Online Terhadap Pembatalan Orderan Makanan (Go-Food) Oleh Konsumen Dengan Pembayaran COD (Cash on Delivery) Dalam Transaksi E-Commerce (Studi Pada PT. Go-Jek Indonesia Kantor Operasional Medan)" (Universitas Sumatera Utara, 2020),
}

Pasal 1476 KUH Perdata menyatakan bahwa biaya penyerahan ditanggung oleh penjual, sedangkan biaya penerimaan atau pengambilan barang ditanggung oleh pembeli. Meskipun begitu, Pasal 1494 KUH Perdata kemudian menjelaskan bahwa penjual tetap bertanggung jawab atas apapun yang berupa akibat dari suatu perbuatan yang dilakukan olehnya, dalam hal ini jika terjadinya ketidaksesuaian atau kerusakan barang yang diterima oleh pembeli. Selanjutnya, disebutkan dalam ketentuan Pasal 1708 KUH Perdata bahwa kurir selaku penerima titipan tidak sekali pun bertanggung jawab atas hal-hal yang dapat menyebabkan kerusakan atau ketidaksesuaian terhadap barang yang dititipkannya tersebut, kecuali kerusakan atau ketidaksesuaian tersebut terjadi karena kesalahan atau kelalaian dari kurir. Kemudian, menurut pasal tersebut juga bahkan kurir tidak perlu bertanggung jawab apabila barang tersebut mengalami kerusakan, bahkan musnah ketika telah berada di tangan pembeli. Hal tersebut juga dinyatakan dalam Pasal 1504 dan 1505 KUH Perdata, bahwa dalam hal terjadinya kerusakan atas barang baik yang tersembunyi maupun yang terlihat jelas sehingga menyebabkan pembeli menolak untuk membayar, maka penjual adalah pihak yang wajib untuk bertanggung jawab, bukan kurir.

Adapun selanjutnya merujuk pada Pasal 1715 KUH Perdata yang kembali menegaskan bahwa penerima titipan hanya berkewajiban untuk mengembalikan barang tersebut sebagaimana barang tersebut dititipkan kepadanya. Mengenai kekurangan atau kerusakan barang tersebut bukan merupakan salah penerima titipan, melainkan tanggung jawab penitip barang (penjual). Apabila dalam sistem COD pembeli menolak untuk membayarkan barang tersebut atas hal-hal di atas, maka kurir memiliki alasan yang sah untuk membebaskan diri dari barang tersebut walaupun belum dibayarkan atau orang yang 
seharusnya menerima barang tersebut menolak, sebagaimana dinyatakan dalam Pasal 1726 KUH Perdata. Selanjutnya, jika terhadap hal tersebut kurir mengalami kerugian, seperti keterlambatan atas pengiriman barang-barang ke alamat lain atau bahkan pemotongan upah oleh perusahaan, maka penjual diwajibkan untuk bertanggung jawab, sebagaimana dinyatakan dalam Pasal 1728 KUH Perdata. Pasal 1729 KUH Perdata pun menambahkan bahwa kurir berhak untuk menahan barang atas apapun yang harus dibayarkan kepadanya atas penitipan tersebut.

Selanjutnya, dalam hal kurir menggantikan perusahaan dalam melaksanakan kuasanya, maka menurut Pasal 1803 KUH Perdata, perusahaan bertanggung jawab atas kurir tersebut. Dalam Pasal 1809 juga kembali ditegaskan bahwa penjual selaku pemberi kuasa dalam hal ini harus memberikan ganti rugi kepada kurir, selaku orang yang menggantikan penerima kuasa, terhadap kerugian-kerugian yang dialami selama kurir menjalankan kuasanya tersebut. Selain pasal-pasal yang telah disebutkan, Pasal 29 ayat (3) UU No. 38 Tahun 2009 tentang Pos juga menegaskan bahwa penyelenggara pos, dalam hal ini perusahaan jasa pengiriman barang yang diwakilkan oleh kurir, tidak dapat dituntut jika barang yang dikirimkan tidak sesuai dengan yang disebutkan oleh penjual ketika hendak mengirim barang tersebut. Karena kurir merupakan seseorang yang diangkat oleh beberapa orang lainnya (penjual dan perusahaan jasa pengiriman barang) untuk mewakili suatu urusan yang dalam hal ini adalah pengantaran barang, maka masing-masing dari mereka harus bertanggung jawab terhadap kurir atas kerugian yang dialami sebagai akibat dari pemberian kuasa tersebut, sebagaimana diatur dalam Pasal $1811 \mathrm{KUH}$ Perdata. Menurut Pasal 1450 KUH Perdata, kurir yang merasa hak-haknya dirugikan dalam menjalankan tugasnya dapat menuntut atas pembatalan perikatan yang telah dibuat, dalam hal ini kurir dapat membatalkan dalam menjalankan kuasa dari perusahaan.

\section{PENUTUP}

Berdasarkan pembahasan yang telah diuraikan di atas, maka dapat disimpulkan bahwa kedudukan kurir dalam sistem pembayaran COD belanja online adalah sebagai orang yang menggantikan perusahaan jasa pengiriman barang dalam menjalankan kuasa yang diberikan oleh penjual kepadanya dalam hal pengiriman barang kepada pembeli, sebagaimana diatur dalam Pasal 1792 - 1819 KUH Perdata tentang pemberian kuasa. Kurir juga berperan sebagai penerima titipan yang dipercayakan untuk menyimpan barang untuk dikirim kepada pembeli, sebagaimana diatur dalam Pasal 1694 - 1739 KUH Perdata tentang penitipan barang. Selain itu, kurir juga berperan sebagai seseorang yang menerima pembayaran dari pembeli untuk diteruskan ke penjual, sebagaimana diatur dalam Pasal 1382 - 1456 KUH Perdata tentang pembayaran. Perlindungan hukum yang dapat diberikan kepada kurir dalam sistem COD belanja online adalah dengan menjamin bahwa ketidaksesuaian atau kesalahan terhadap barang yang dipesan bukan merupakan tanggung jawab kurir, apabila hal tersebut bukan diakibatkan kesalahan atau kelalaian kurir, sebagaimana diatur dalam Pasal 1708 KUH Perdata. Terhadap kerugian yang dialami oleh kurir, wajib digantikan dan dipertanggungjawabkan oleh penjual, apabila ketidaksesuaian dan kerusakan barang dari awal adalah akibat dari kesalahan penjual. Selanjutnya, atas pengembalian barang, maka pembeli seharusnya mengikuti ketentuan yang telah ditetapkan oleh marketplace, yaitu dengan cara melaporkan barang yang ingin dikembalikan melalui platform yang sebelumnya digunakan untuk memesan barang, bukan kepada kurir. 


\section{DAFTAR PUSTAKA}

Asmadi, Erwin. "Aspek Perlindungan Hukum Bagi Konsumen Dalam Penggunaan Aplikasi Pembayaran Elektronik (Electronic Payment)." Doktrina : Journal of Law 1, no. 2 (2018): 90-103.

Asmara, Teguh Tresna Puja, and Tri Handayani. "Ketidakpastian Hukum Penggunaan Kode Unik Dalam Sistem Pembayaran E-Commerce." Jurnal Penelitian Hukum De Jure 19, no. 4 (2019): 503-16.

Azizah, Mabarroh. "PENERAPAN ETIKA BISNIS ISLAM DALAM TRANSAKSI JUAL BELI DARING DI TOKO ONLINE SHOPEE." Humani (Hukum Dan Masyarakat Madani) 10, no. 1 (May 22, 2020): 83-96. https://doi. org/10.26623/HUMANI.V10I1.1848.

Febrian, Ramdan. "Sialnya Jadi Kurir Pengiriman Paket: Tanggung Jawab Besar Tapi Perlindungan Hukum Minim.” VOI, 2021.

Gulo, Setiawati. "Transaksi E-Commerce Dengan Sistem Cash on Delivery Dalam Perspektif Peraturan PerundangUndangan Di Indonesia." Universitas Jambi, 2021.

Harun, Suryaningsih, Weny A Dungga, and Abdul Hamid Tome. "Implementasi Asas Itikad Baik Dalam Perjanjian Transaksi Jual Beli Online." Jurnal Legalitas 12, no. 2 (2018): 90-99.

Lidwina, Andrea. "Penggunaan E-Commerce Indonesia Tertinggi Di Dunia." Databoks, April 2021.

Lomboe, Alfred Perlin Jaya. "Perlindungan Hukum Bagi Driver Online Terhadap Pembatalan Orderan Makanan (Go-Food) Oleh Konsumen Dengan Pembayaran COD (Cash on Delivery) Dalam Transaksi E-Commerce (Studi Pada PT. Go-Jek
Indonesia Kantor Operasional Medan).” Universitas Sumatera Utara, 2020.

Lumba, Hermawan, and Sumiyati. "Pertanggungjawaban Perusahaan Ekspeditur Kepada Konsumen Berdasarkan UU No. 8 Tahun 1999 Tentang Perlindungan Konsumen." Mimbar Keadilan Jurnal Ilmu Hukum, no. 8 (2014): 71-86.

Maharrani, Anindhita. "Orang Indonesia Pilih CoD Saat Belanja Online.” Lokadata, January 2021.

Pardede, Grace Evelyn, and Ferdinand Sujanto. "URGENSI PENYERAGAMAN KEBIJAKAN COD PADA MARKETPLACE INDONESIA DEMI MEWUJUDKAN PERLINDUNGAN HUKUM" 1, no. 2 (2021): 12-28.

Pernando, Nedi, Busyra Azheri, and Wetria Fauzi. "Perlindungan Hukum Terhadap Konsumen Atas Kerusakan Barang Pengguna Jasa Pengiriman Angkutan Online." Journal of Chemical Information and Modeling 4, no. 1 (2021): 135-49.

Pink, Bidara. "YLKI Catat Selama Pandemi Aktivitas Belanja Online Meningkat Hingga 30\%." Kontan.co.id, January 2021.

Qamar, Nurul, Aan Aswari, Hardianto Djanggih, Muhammad Syarif, Dachran S. Busthami, M. Kamal Hidjaz, and Rezah Farah Syah. Metode Penelitian Hukum (Legal Research Methods). Edited by Abd. Kahar Muzakkir. 1st ed. Makassar: CV. Social Politic Genius (SIGn), 2017.

Saputra, Arikha, Muzayanah, and Fitika Andraini. "Penerapan Perjanjian Dalam Hubungan Kerja Dan Perlindungan Hukum Bagi Driver Online." Jurnal Komunikasi Hukum (JKH) 6, no. 1 (2020): 266. https://doi.org/10.23887/ jkh.v6i1.23529. 
Simanjuntak, Salomo Kevin Davian. "Tinjauan Yuridis Terhadap Tanggung Jawab Penyelenggara Layanan E-Commerce Terhadap Konsumen Situs Lazada.Co.Id.” Universitas Sumatera Utara, 2019.

Simanullang, Heldya Natalia. "Perlindungan Hukum Terhadap Konsumen Dalam Transaksi E-Commerce." Melayunesia Law 1, no. 1 (2017): 111-26.

Stephanie, Conney. "Rentetan Kasus COD, Mengancam Kurir Hingga Paket Tak Bertuan.” Kompas.com, 2021.

Sugesti, Chory Ayu, Si Ngurah Ardhya, and Muhamad Jodi Setianto. "Perlindungan Hukum Terhadap Pelaku Usaha Online Shop Yang Mengalami Kerugian Yang Disebabkan Oleh Konsumen Di Kota Singaraja." Jurnal Komunitas Yustisia Universitas Pendidikan Ganesha 3, no. 3 (2020): 166-75.
Suriyadi. "Tanggung Gugat Penjual Dan Jasa Pengantaran Dalam Transaksi Jual Beli Online Dengan Metode Cash on Delivery." El-Iqtishady Jurnal Hukum Ekonomi Syari'ah 3, no. 1 (2021): 32-43.

Wahyuni, Sri. "Perlindungan Hukum Terhadap Konsumen Pemilik Kartu Kredit Dalam Transaksi E-Commerce (Studi Pada Bank X Medan)." Universitas Sumatera Utara, 2019.

Yaqin, Ainul. "Akibat Hukum Wanprestasi Dalam Jual Beli Online Menurut UndangUndang Informasi Dan Transaksi Elektronik.” Dinamika 25, no. 6 (2019): 9-19.

Zulaeha, Mulyani. “Tanggung Jawab Dalam Levering Pada Perjanjian Jual Beli Secara Online." Lambung Mangkurat Law Journal 4, no. 2 (2019): 176-89. 